\title{
ENERJİ SÜBVANSİYONLARININ ETKİLERİ VE TÜRKİYE AÇISINDAN AMPİRIK BİR DEĞERLENDİRMESİ
}

\author{
Hakan AKAR*, Filiz GİRAY**, Mehmet ÇINAR ${ }^{* * *}$
}

Makale Geliş Tarihi-Received: 11.04.2021

Makale Kabul Tarihi-Accepted: 20.11.2021

DOI: $10.37093 /$ ijsi.971913

ÖZ

Enerjinin kullanım alanları ve işlevlerine binaen hükümetler tarafindan desteklenmeleri söz konusu olmaktadır. Bu desteklerin başında sübvansiyonlar gelmektedir. Günümüzde birçok ülke her yıl gayrisafi yurtiçi hasılaları (GSYİH)'nın önemli bir kısmını enerji sübvansiyonlarına ayırmaktadırlar. Çeşitli enerji kaynakları olmakla birlikte enerji elde etmek için dünyada en çok başvurulan fosil yakıtlardır. Ancak fosil yakıtların neden olduğu olumsuz etkiler bu alandaki sübvansiyoların da sorgulanmasını gündeme getirmiştir. Bu çalışmanın amacl, enerji sübvansiyonlarının çevresel, ekonomik ve sosyal etkilerini Türkiye uygulaması ile incelemektir. Böylece Türkiye açısından elde edilen bulguların ışığı altında izlenecek enerji sübvansiyonu politikası konusunda önerilerde bulunulabilinecektir. Bu çerçevede Türkiye için 1990-2018 dönemi verileri kullanlarak ARDL

* Arş. Gör., Bursa Uludağ Üniversitesi, İktisadi ve İdari Bilimler Fakültesi, Maliye Bölümü, Bursa/Türkiye. hakanakar@uludag.edu.tr, ORCID: https://orcid.org/ 0000-0002-2145-5894.

** Prof. Dr., Bursa Uludă̆ Üniversitesi, İktisadi ve İdari Bilimler Fakültesi, Maliye Bölümü, Bursa/Türkiye. giray@uludag.edu.tr, ORCID: https://orcid.org/00000002-8765-8248.

*** Prof. Dr., Bursa Uludă̆ Üniversitesi, İktisadi ve İdari Bilimler Fakültesi, Ekonometri Bölümü, Bursa/Türkiye. mcinar@uludag.edu.tr, ORCID: https://orcid.org/0000-0001-8441-243X. 
eştümleşme analizi ve Toda-Yamamoto nedensellik analizi uygulanmıştır. Analiz sonuçlarna göre Toda-Yamamoto nedensellik analizi ile enerji sübvansiyonlarn ve çevresel etkiler arasında kısa vadede tek yönlü ilişki olduğu bulunmuştur. Bu sonuca göre enerji sübvansiyonlarının aşamal olarak tamamen kaldırilması, küresel CO2 emisyonların \%5,8 azaltabilme potansiyeline sahiptir. Eştümleşme analiz sonuçlarna göre, enerji sübvansiyonlarının uzun dönemli ekonomik etkilerine rastlanmamıştır. Sosyal etkiler açısından da eştümleşme analizine göre enerji sübvansiyonlarmın işsizlikle olan ilişkisi uzun dönemde anlamsiz bulunmuştur. Bu bulgulara dayah olarak Türkiye'de de enerji sübvansiyon politikalarından değiş̧im yapılması gerektiği söylenebilir.

384

Anahtar Kelimeler: Enerji Sübvansiyonları, Sübvansiyonlar, Fosil Yakıtlar, ARDL Eştümleşme Analizi, Toda-Yamamoto Nedensellik Analizi.

JEL Kodlari: H23, Q52, Q53, Q58. 


\title{
EFFECTS OF ENERGY SUBSIDIES AND AN EMPIRICAL ASSESSMENT OF TURKEY IN TERMS
}

\begin{abstract}
Energy uses and functions are supported by governments. At the beginning of these supports are subsidies. Currently, many countries allocate a significant portion of their gross domestic product (GDP) to energy subsidies every year. Although there are various energy sources, they are the most commonly used fossil fuels in the world to obtain energy. But the negative effects caused by fossil fuels have also raised questions about subsidies in this area. The aim of this study is to examine the environmental, economic and social effects of energy subsidies with the application of Turkey. In this way, suggestions can be made on the energy subsidy policy to be followed in the light of the findings obtained from Turkey's point of view. In this context, ARDL co-ordination analysis and Toda-Yamamoto causality analysis were applied for Turkey using 1990-2018 period data. According to the results of the analysis, it was found that there is a one-way relationship between the Toda-Yamamoto causality analysis and energy subsidies and environmental effects in the short term. According to these results, the gradual abolition of energy subsidies altogether has the potential to reduce the global CO2 emissions by $5.8 \%$. Also, the results of the co-ordination analysis, the longterm economic effects of energy subsidies were not observed. In term of social effects, according to the co-integration analysis, the relationship of energy subsidies with unemployment has been found to be meaningless for a long time. Based on these findings, it can be said that energy subsidy policies should be changed in Turkey as well.
\end{abstract}

Keywords: Energy Subsidies, Subsidies, Fossil Fuels ARDL Cointegration Analysis, Toda-Yamamoto Causality Analysis.

JEL Codes: H23, Q52, Q53, Q58. 


\section{GİRIŞ̧}

1970'lerdeki petrol krizinden bu yana dünyada enerji sektörüne yönelik kamu müdahaleleri giderek yaygınlaşmıştır. Günümüzde hükümetlerin enerji, tarım ve su sektöründe uyguladığ1 sübvansiyonları (çoğunluğu üretici sübvansiyonu) 1.1 trilyon dolara ulaşmaktadır. Bu uygulama doğal kaynak fiyatlarını sunî olarak düşük tutmaktadır. Konuya enerji özelinde bakıldığında ise pek çok ülke her yıl GSYİH'lerinin \%5 veya daha fazlasını enerji sübvansiyonlarına ayırmaktadır. Enerji elde etmek için de fosil yakıtlar dünyada en çok başvurulan doğal kaynaklardır (Oppenheim vd., 2011: 84). Fakat fosil kaynakların çıkarılmasıyla beslenen ekonomik büyüme, borçla beslenen ekonomik büyümeye çok benzemektedir. Fosil kaynaklar çıkarılıp kullandığında, ekonomik aktiviteyi artırmak da yenilenemez doğaları gereği, daha sonraki yıllarda kullanılması gereken kaynakların erken tükenmesine ve doğal kaynak darboğazına neden olabilir. Dolayısıyla bugün verilen bir ekonomik teşvik, yarın ekonomik bir engele dönüşebilir. Bunun sonucunda gelecekteki karşılaşılabilecek ekonomik zorluklar ve maliyetler genellikle bugün verilen teşviklerden daha büyük olmaktadır (Konrad, 2011).

Fosil yakıt sübvansiyonları, kaynakların ekonomik olarak verimsiz bir şekilde tahsis edilmesine ve piyasa çarpıklıklarına neden olduklarından, çoğu zaman bu sübvansiyonlarla amaçlanan ekonomik hedefler de karşılanamayabilir. Mesela enerji fiyatlarını önemli ölçüde düşüren sübvansiyonlar atık üretimini teşvik eder, piyasa sinyallerini bulanıklaştırarak enerji fiyatındaki oynaklığı şiddetlendirir ve ekonomide kullanılan yakıt yoğunluğunu artırır. Ayrıca sübvansiyonlar, yenilenebilir enerji kaynaklarının ve daha verimli enerji teknolojilerinin fosil kaynaklarla olan rekabet gücünü zayıflatır. Enerji kaynağı ithal eden ülkeler açısından sübvansiyonlar, genellikle devlet bütçeleri üzerinde belirgin bir ölçüde yük getirirken, üreticiler açısından bakıldığında kaynakların tüketilmesini hızlandırmakta ve böylece uzun vadede ihracat gelirlerini daha da azaltabilmektedir. Bu politikalarla yoksulluğun azaltılması hedefleri açısından da net olumlu faydalar elde etmek oldukça zor ve maliyetli olabilmektedir. Hatta kimi durumlarda sübvansiyonlar, yaşanan yoksulluğu şiddetlendirme potansiyeline bile sahiptir (OECD, 2005a: 85; Del Granado vd., 2010: 13; IEA, 2010: 569; World Bank 2012; OECD, 2017a: 40; IEA, 2018: 109; Arıboğa, 2019: 33). Dolayısıyla 


\section{Enerji Sübvansiyonlarının Etkileri ve Türkiye Açısından \\ Ampirik Bir Değerlendirmesi}

sübvansiyonlar genellikle ekonomik ve sosyal amaçlarla uygulansa da etkileri çevreyi de kapsayacak şekilde daha geniş olmaktadır. Bu durum sübvansiyonları çok fazla tartışılan konu haline getirmektedir. Özellikle sübvansiyonların kaynak yetersizliği çeken özellikle gelişmekte olan ülkelerde oldukça maliyetli bir kamu politika aracı olması bile yoğun eleştirilerin odağı haline gelmesine neden olmaktadır.

Yukarıda açıklanan etkiler, küresel çapta enerji sübvansiyonlarının azaltılması yönünde önemli bir hareketlilik yaratmıştır. Örneğin verimsiz fosil yakıt sübvansiyonlarını 2009 Eylül'ünde G-20 liderleri, aynı yılın Kasım'ında da Petrol İhraç Eden Ülkeler Örgütü (OPEC) liderleri, aşamalı olarak kaldırmayı ve rasyonelleştirmeyi taahhüt etmiştir. Fakat birçok ülke son yıllarda bu yönde reformlar sürdürse de kazanımlarda kalıcılığı sağlamak için ekonomik, politik ve sosyal engellerin bütüncül olarak üstesinden gelinmesi gerekmektedir. Verimsiz enerji sübvansiyonlarının azaltılması bazı etkiler yaratacaktır: Öncelikle küresel enerji piyasalarındaki arz ve talep dengeleri değişecektir. Bu konuda yapılan bir araştırmaya göre tüm fosil yakıt tüketim sübvansiyonlarının küresel çapta 10 yılda aşamalı olarak durdurulması, sübvansiyonların hiç değişmediği duruma kıyasla küresel birincil enerji talebini $\% 5$ oranında azaltabilir. Bu oran Japonya, Kore ve Yeni Zelanda'nın 2010 yılındaki enerji tüketimlerinin toplamına eşittir. Aynı politikanın petrol talebi üzerindeki etkisi de, ABD'de 2010 yılı toplam talebinin dörtte biri kadar azalma şeklinde olacaktır (IEA, 2010: 569).

Ayrıca fosil yakıt tüketim sübvansiyonlarının kaldırılması, iklim değişikliği ile mücadelede ayrılmaz bir yapı taşı olabilir. 2020 yılına kadar aşamalı olarak sübvansiyonların tamamen bitirilmesi, karbondioksit (CO2) emisyonlarını \% 5,8 veya 2 Gigaton (Gt) azaltabilme potansiyeli vardı (IEA, 2010: 569). 2015 yılından beri çok verimli olmayan fosil yakıt sübvansiyonlarının kaldırılması konusunda bazı ilerlemeler kaydedilmiştir. Ancak gerçekleşen emisyon azalışı öngörülenden daha azdır. Petrol ve gaz işlemlerinden kaynaklanan metan emisyonu tahminleri, üretimle orantılı olarak dönem boyunca artmıştır ve bu da iklim değişikliği önlemleri konusunda neredeyse hiç ilerleme kaydedilmediğini gösterir (IEA, 2018: 109). Türkiye'de verilen enerji sübvansiyonlarının enerji fiyatları, enerji tüketimi, enerji ithalatı, cari denge, kamu maliyesi, gelir dağılımı üzerindeki etkileriyle ilgili çalışmalar sınırlıdır. Bu 
konulardaki çalışmalar sübvansiyon reformlarına yol gösterici olabilir. Bu çalışma ile Türkiye'de enerji sübvansiyonlarının doğurduğu ekonomik, sosyal ve çevresel sonuçlar Türkiye özeli ile ampirik olarak araştırılacaktır. Böylece ekonomik, sosyal ve çevresel açıdan bir sorun olan enerji alanlarını azaltmak üzere bir önlem olarak bu alanlardaki sübvansiyon politikalarında yapılması gereken değişiklikler önerilerek katkı sağlanabilecektir. Bu amaçla, çalışmanın beş ana başlıkla toplanmaktadır. Takip eden bölümde enerji sübvansiyonlarının ekonomik, sosyal ve çevresel etkileri açıklanmaktadır. Daha sonra örnek ülke olarak Türkiye alındığı için

\section{ENERJİ SÜBVANSİYONLARININ EKONOMİK, SOSYAL VE ÇEVRESEL ETKILLERI}

Sübvansiyon uygulamalarından maksat toplumsal refahin artırılmasıdır ve toplumda refah artışına en çok ihtiyacı olanlarsa yoksullardır. Kahverengi sübvansiyonlar olarak geçen zararlı sübvansiyonlar ise yoksullara fayda sağlaması bir yana, bazı durumlarda zararlı da olabilir. Sübvansiyonların tüm ekonomiye yayılan etkisiyle ve bütçeye yüklenen ek yük nedeniyle, hükümetlerin temel hizmetlerdeki arz maliyetlerinin tamamını karşılayamaması ülkede yoksulluğu daha da şiddetlendirebilir. Enerji sübvansiyonları sonucu ortaya çıkan kamu gelir kaybı, hükümet bütçesinde sürekli bir açığa dönüşmektedir. Yetersiz kamu gelirleri mesela su ve enerji hizmetlerine erişimi olmayanların faydalanmasına sunulmak üzere arzı genişleten yatırımlar yapabilme ve hizmet kalitesinde ihtiyaç duyulan artışların gerçekleştirilebilme kapasitesini sınırlar (OECD, 2017). Tüketici sübvansiyonları genellikle düşük gelirli hane halklarına refah aktarımı için oluşturulmaktadır. Fakat sübvansiyonlar bazı toplumsal kesimlerde refah artışını sağlasa da yoksullara sağladığı faydalar şüphelidir. İyi hedeflenmeyen mali destekler, genellikle harcamaların büyük bir kısmının yüksek gelirli hanelere sızmasına neden olmaktadır. Düşük gelirli hane halklarına yönelik hedeflenen geniş tabanlı sübvansiyonlar, bazı durumlarda haklı gerekçeleri olsa da olumsuz mali ve çevresel etkiler yaratmakta 


\section{Enerji Sübvansiyonlarının Etkileri ve Türkiye Açısından \\ Ampirik Bir Değerlendirmesi}

ve yoksulluğu azaltma hedeflerine etkin bir şekilde ulaşılmasını sağlayamamaktadır (OECD, 2005b: 85).

Tüketici sübvansiyonlarının bir diğer özelliği olan faydalarının genellikle tüm tüketicilere yayılması, sübvansiyonlara rağmen en yoksul kesimlerin temel hizmetlere erişimi hala sınırlı kalmakta sübvanse edilen mal ve hizmetlerin bir kısmını ("açlık seviyesi" eşiğine yaklaştıkça bu ihtimal artar) diğer hane halklarına satabilmektedirler. Sübvansiyon avantajlarının büyük oranda en yüksek gelir gruplarına sızması, küresel yakıt sübvansiyonlarının yoksul hanelerin refahını koruma işlevini oldukça maliyetli hale getirmektedir. Örneğin, hanelerin en yoksul \% 20'si sübvansiyon politikasında hedef "yoksul" grup kabul edilirse, bu gruba bir dolarlık gelirin benzin sübvansiyonları yoluyla aktarılmasının kamu bütçesine maliyeti 33 dolar civarındadır. Bu oran, her 100 dolarlık benzinden 97'sinin ilk dört \% 20'lik gelir dilimlerine "sızıntı" yaptığını yansıtır. Dolayısıyla istenen refah artışı için 33 kat daha fazla kamu kaynağı gerekmektedir. Ülkeler bunun yerine, böyle genel destekleri yoksullar için daha iyi hedeflenen desteklere kaydırırsa, fonlar en az ihtiyacı olanlara değil, en çok ihtiyaç duyan insanlara fayda sağlayacaktır (World Bank, 2012). Hatta en yoksul \% 20'lik dilimdekiler gazyağını en çok kullanan gelir gruplarından biri olmasına rağmen, gazyağı sübvansiyonunun kamuya maliyet-fayda oranı 5 dolar civarındadır. Yani 100 dolarlık gazyağı sübvansiyonunda bu gelir grubu sadece 19 dolar kadar faydalanabilecektir. Diğer bir ifadeyle yoksul kesimlerde istenen refah artışı için 5 kat daha fazla kamu harcamasını gerektirmektedir. 2010 öncesi hazırlanan bir rapora göre, fosil yakıt sübvansiyonlarından elde edilen faydaların \% 80'inden fazlasının genellikle en yüksek ilk üç gelir grubuna gittiğini tahmin etmiştir (Del Granado vd., 2010: 13).

Sübvansiyonlar kamu politikası aracı olarak belirli sektörleri ve/veya üretici ve tüketicileri korumak amacıyla kullanılırlar. Sübvansiyonlar ile mal ve hizmetleri fiyatları düşük tutulabilmektedir. Ancak sübvansiyonlar bazen yukarıda bahsedildiği üzere beklentileri karşılamayıp olumsuz etkiler yaratabilmektedirler. Ülke bazlı yapılan analizlerde, ülkelere göre genel olarak sübvansiyonların olumlu ve olumsuz sonuçları görülebilmektedir. Hatta aynı ülkede tasarruf edilen kamu fonlarının tekrar ekonomiye aktarılıp aktarılmamasına göre farklı sonuçlar çıkabilmektedir. Ancak dünya genelinde son yıllarda belirli sektörlere verilen sübvansiyonların ekonomik, sosyal 
ve çevresel açıdan olumsuz etkiler yaydığı görülmektedir. $\mathrm{Bu}$ sektörlerin başında enerji sektörü gelmektedir. Enerji kaynağı olarak en fazla kullanılan fosil yakıt tüketim sera gazı emisyonunu artırıp çevre kirliliği yaratmaktadır. Yine birçok ülkede üretici sübvansiyonlarının büyük bir kısmı, üretim ve ticaret şekillerini serbest piyasa koşullarından uzaklaştıran yöntemlerle sağlanmaktadır. Bu durum enerji sektöründe de görülmektedir. Dolayısıyla bu uygulamaların neden olduğu büyük refah kayıpları kaçınılmaz olmaktadır. OECD tarafından yapılan bir araştırma kapsaminda 2014-2016 döneminde üreticiler için verilen sübvansiyonun üçte ikisinden daha fazlasının bu özelliklere sahip olduğu görülmektedir. Örneğin Kore hükümetinin sağladığı sübvansiyonların yarısı üretici odaklı ve bunun da \% 94'ü piyasa rekabetini bozucu niteliktedir. Benzer özelliğe sahip diğer ülkeler sıralamasında İzlanda, Japonya, İsviçre, Norveç ve Türkiye gelmektedir. Ayrıca bu tür destekler, arazi kullanımını artıran daha uygun ortamlar sağladığı için çevre üzerinde olumsuz etkileri de artırır (OECD, 2017a: 45).

Bu gerçekler doğrultusunda enerji sübvansiyonlarının azaltılmasına yönelik çalışmalar yapılmaktadır. Örneğin Çin'de tüm enerji sübvansiyonlarının kaldırılmasını yönelik yapılan çalışmada üç senaryo oluşturulmuştur. İlki sübvansiyonların kaldırılmasıdır. Ancak enerji sübvansiyonlarının kaldırılması durumunda, enerji fiyatlarının genel seviyesindeki artış nedeniyle makroekonomik değişkenler önemli ölçüde olumsuz etkilere maruz kalabilecektir. Bu değişkenler olarak refah, GSYİH ve istihdam ise sirasiyla \% 2,03, \% 1,56 ve \% 1,41 oranında azalacaktır. Buna karşın, \% 3,56 azalacak olan enerji yoğunluğunda önemli bir gelişme görülecektir. Yoğunluk azalışı beklendiği gibi, $\mathrm{CO} 2$ ve SO2 emisyonlarında sırasıyla \% 7,02 ve \% 6,83 oranında büyük bir düşüşü beraberinde getirecektir. Bu durum, Çin gibi gelişmekte olan bir ülkede enerji fiyatındaki artışın enerji verimliliğini artırmak ve emisyonu azaltmak için kilit faktör olduğunu göstermektedir (Lin, Jiang, 2011: 280).

Çin analizindeki ikinci senaryo olan mevcut enerji sübvansiyonlarının kaldırılması ve bu sübvansiyonların \% 35'inin ekonomiye yeniden tahsis edilmesidir. Bu tasarruf tutarı enerji yoğunluğu ve emisyonu daha az olan tarım, hizmetler ve hafif sanayi lehine yeniden tahsis edilmesi gerekmektedir. Diğer bir ifadeyle yeniden tahsis de ağır sanayi dikkate alınmamaktadır. Bu çerçevede refah, GSYİH ve 


\section{Enerji Sübvansiyonlarının Etkileri ve Türkiye Açısından Ampirik Bir Değerlendirmesi}

istihdam bu kez sırasıyla \% 0,16, \% 0,37 ve \% 0,53 oranında artacaktır. Birinci durumdaki sonuçlarla karşılaştırıldığında, enerji yoğunluğunda düşüş \% 2,79 oranında daha az gerçekleşecektir. Benzer şekilde, CO2 ve SO2 emisyonları da sırasıly \% 5,91 ve \% 4,83 oranında daha az bir oranda düşecektir. Fonların ekonomiye yeniden dağıtılması, emisyon azaltımlarını bir miktar tekrar ortaya çıkaracağından, emisyonların daha az düşmesi doğal bir sonuç olarak karşılanabilir.

Son senaryo tasarruflarm \% 50'sinin yeniden tarım, hizmet ve hafif sanayiye tahsis edilmesi şeklindedir. $\mathrm{Bu}$ yeniden dağıtımda ise makroekonomik değişkenler üzerindeki olumlu etkiler ikinci'ye göre daha fazla olacaktır. Şöyle ki refah, GSYİH ve istihdam sırasıyla \% $1,52, \% 1,74$ ve \% 2,07 artacaktır. Bununla birlikte, enerji yoğunluğu ve emisyonlarda hala azalma görülse de, ilk iki durumla karşılaştırıldığında daha küçük bir oranda azalacaktır (Lin, Jiang, 2011: 281).

Yine Anderson ve McKibbin (1997) çalışmalarında OECD ekonomilerinde kömür üretiminin önemli ölçüde sübvanse edildiğini belirtmektedirler. Ayrıca gelişmekte olan ülkelerde ve geçiş ekonomilerinde önemli kömür sübvansiyonlarının olduğunu bu ülkelerde üretim sübvansiyonlarının kademeli olarak kaldırılması ve kömür piyasasındaki aksaklıkların giderilmesi sonucu küresel emisyon miktarında \% 8'e kadar azalma sağlayabilecektir (Anderson, McKibbin, 1997: 20).

Enerji sübvansiyonlarının yarattığı olumsuz etkiler ekonomik, sosyal ve çevresel olarak kategorize edilse de bu etkilerin birbiriyle bağlantılı olduğu görülmektedir. Yapılan çalışmalar, gelişmiş ülkelerde enerji sübvansiyonunun kaldırılmasının bir çevre göstergesi olan sera gazı emisyonlarında çok önemli bir azalmaya ve ekonomik verimliliğin artmasına neden olacağını göstermektedir. Enerji sübvansiyonlarının kaldırılması diğer değişkenleri kimi zaman farklı etkilenebilse de sera gazı emisyonlarında düşüşler beklenmektedir (Saunders, Schneider, 2000: 10-20, 34; IEA, 2001: 252; Burniaux vd., 2009; Burniaux, Chanteau, 2010: 10; Lin, Jiang, 2011: 280; IPC, 2016: 47). IPC tarafından yapılan bir başka araştırmada da fosil yakıtlara en çok sübvansiyonun verildiği ve OECD ülkesi olmayan 37 ülkede, sübvansiyonlar 2013'ten 2020'ye kadar kademeli olarak kaldırılmış olsaydı, 2050'ye kadar dünya CO2 emisyonları \% 13, sera gazı emisyonları \% 8 ila 10 
arasında azaltılabileceği tespit edilmiştir. Refah kazanımları ise \% 0.3 civarında olacaktır. Elektrik sübvansiyonları kaldırılmadığı durumda emisyon azalışı \% 7,6 ile, refah kazanımları ise \% 0,1 ile sınırlı kalacaktır. Eğer sübvansiyonların kaldırılmasına emisyon ticareti (cap and trade) politikası eşlik ederse emisyona ve refaha olumlu katkısı sırasıyla $\% 9,8$ ve $\% 0,3$ gerçekleşir. Ayrıca bu politika senaryolarında fosil yakıt arz elastikiyeti ile refah ters orantıll, çevresel etkiler ile doğru orantılı olduğu tespit edilmiştir (Burniaux vd., 2009: 34; Burniaux, Chanteau, 2010: 10, 16). Bu durumu destekler nitelikte Vietnam için Birleşmiş Milletler Kalkınma Programı tarafından yapılan araştırmada benzer sonuçlara rastlanmaktadır. Buna göre fosil

Çevreye olumlu etkisi olan enerji kaynaklarının üretim maliyetleri daha düşük olabilmektedir. Örneğin 1MWh elektrik üretimi rüzgâr enerji santralleriyle 3 dolar daha ucuz yapilabilmektedir. Yapilan bir çalışmada 2027' de mevcut kömürlü elektrik santrallerini kullanmaya devam etmek, aynı değerde enerji üreten yeni rüzgâr enerji santralleri yapıp işletmekten daha maliyetli olacaktır. Aynı durum güneş enerji santralleri için de geçerlidir (Carbon Tracker Initiative, 2020). Fakat mevcut kömür sübvansiyonları yenilenebilir enerji teknolojilerinin rekabet gücünü daha da zorlaştırmakta ve yenilenebilir enerji yatırımlarının gelişimini tehlikeye atmaktadır. Ayrıca enerji sistemini fosil yakıt temelli enerji üretimine bağımlı hale getirmektedir (Bridle, Kitson, 2014: 5).

Ayrıca sübvansiyon reformları kamu maliyesi üzerindeki yükü azaltıp üretken yatırımların artışına imkân sağlar. Enerji tüketim sübvansiyonları kaldırıldığında 10 yıl içinde GSYH'ye ilave \% 0,45 katkı sağlayabilir (Saunders, Schneider, 2000: 10-20).

Enerji sübvansiyonları kısıtlamasına yönelik çalışma yapan ülkeler içinde Almanya ve ABD en dikkat çekici örneklerdir. Alman kömür sübvansiyonlarının reformu olarak adlandırılan çalışmada enerji üretiminin dışsallıklarına bakılarak, kömür sübvansiyonlarının çevreye zararlı olduğu, yenilenebilir enerji kaynakları sübvansiyonlarının ise daha az zararlı olduğu belirtilmektedir. Genel olarak Alman kömür sübvansiyonlarının reformunun $\mathrm{CO} 2, \mathrm{SO} 2$ ve partikül emisyonlarında düşüşe ve NOX emisyonlarında artışa yol açacağı ileri sürülmüştür. Ancak orta ve daha uzun vadede, küresel 


\section{Enerji Sübvansiyonlarının Etkileri ve Türkiye Açısından Ampirik Bir Değerlendirmesi}

ve ulusal piyasalar etkileşerek çevresel iyileşme görülebilecektir. ABD enerji sübvansiyonlarının yaklaşık üçte biri Ar-Ge'ye ayrılmaktadır. Bunların çoğu nükleer enerji yakıtlarını, nükleer atıkları ve bunların güvenlik konularını, nihai enerji kullanım verimliliğini, temiz kömür teknolojilerini ve yenilenebilir enerjiyi hedeflemektedir. Sübvansiyonların bu şekilde yeniden düzenlenmesi, gelecekte çevreye daha az zararlı teknolojiler için fırsatların artmasını sağlayabilir (OECD, 2015b: 52, 53).

Enerji sübvansiyonlarına kaldırılması veya kısıtlamasına yönelik temel kaygı sübvansiyon reformu ekonomik verimliliği artırsa da enerji maliyetlerine de etkisinin kaçınılmaz olmasıdır. 2000 yılında OECD ülkelerinde kömür üretimine verilen destekler ton başına ortalama 68 dolardır. (OECD, 2015b: 22, 128). Enerji sübvansiyonlarının kaldırıldığı ekonomilerde kömür fiyatlarını \% 50 'ye varan oranlarda yükselmiştir. Örneğin petrol ürünlerinde yüksek sübvansiyon uygulayan Meksika ve Endonezya'da sübvansiyonların kaldırılması fiyatları sırasıyla $\% \quad 40$ ve $\% 10$ civarında artırmıştır. Toplam tüketici harcamaları içinde küçük bir paya sahip olan Rusya ve Hindistan'da yurtiçi tüketici fiyatlarının artışı küresel fiyatlardaki azalışla dengelenmiştir (Saunders, Schneider, 2000: 10-20).

Sübvansiyon faydalarının toplumsal gruplar arasında dengesiz yansıması, yoksul hanelerin reel gelirlerini korumanın daha etkili yollarının geliştirilmesini gerekli kılmaktadır. Örneğin, gazyağı sübvansiyonlarından bile daha yüksek olan bir sosyal güvenlik ağı programina tahsis edilen fonların maliyet-fayda oranları 1,5 dolardır (1/0,68 dolar). Yani sosyal güvenlik ağına yapılacak katkının \% 68'i hedefini bulmaktadır. Ayrıca akaryakıt piyasalarını ciddi bir şekilde bozmadan gazyağı sübvansiyonları yoluyla fakirlere verilebilecek desteğin kapsamı çok sınırlıdır. Nispeten düşük gazyağı fiyatları, mazot yerine (yasal veya yasadışı olarak) ikame edilmesine neden olmakta ve çoğu zaman ülke sınırına yakın haneler daha yüksek fiyatların olduğu komşu ülkelere kaçak yollarla satmak istemektedir (Del Granado vd., 2010: 13).

Modern enerji erişimi düşük düzeyde olan ülkelerde, konutlardaki genellikle yoksulların temel ihtiyaçlarını destekleyen gazyağı, elektrik ve LPG gibi yakıtlar için sübvansiyonlar 2009 yllında fosil yakıt tüketim sübvansiyonlarının sadece \% 15 'ini oluşturmuştur. Fakat 
bunların kaldırılması düşük gelirli hane halklarını daha ağır etkilenme ihtimali olduğundan sübvansiyon reform programlarının dikkatle tasarlanması gerekmektedir. Yakıt sübvansiyonlarının kaldırılmasının, yoksul haneler üzerinde ilk başlarda büyük ölçüde olumsuz bir etkisi olabilmektedir. Bunun için kısa vadede bir taraftan gazyağı destekleri azaltılırken, diğer taraftan yoksul kesimi hedefleyen okul yemekleri, eğitim ve sağllk hizmetleri, şehir içi toplu taşıma bedelleri düşürülüp, belirli bir gelirin altındaki hane halkının su ve elektrik tüketimi için sübvansiyonlarının sürdürülmesi tercih edilebilir (IEA, 2010: 569; Del Granado vd., 2010: 13). Bu amaçla 2016

Herhangi bir sektörün istidam olanakları, o sektörün sosyal etkileriyle doğrudan bağlantılıdır. Kişilere net olmayan politikalarla refah artışı sağlamak yerine yeni ve daha fazla istihdam oluşturmak alternatif bir politika olabilir. 2017 yılında küresel enerji sektöründe 58 milyon kişi istihdam edilmiştir. Bunun yaklaşık yarısı fosil yakıt bağlantılı sektörlerde gerçekleşmiştir (Czako, 2020: 14). Fakat politika yapıcılar tarafından dikkat edilmesi gereken toplam istihdam rakamlarından ziyade o sektörün istihdam potansiyelidir. Buna göre, 2015 yılında ABD'de 1 milyon dolarlık enerji verimliliği ve yenilenebilir enerji yatırımlarının sağlayacağı iş olanakları, fosil yakıt yatırımından 3 kat daha fazladır. Bununla birlikte, bu işlerin çalışma koşulları daha iyi ve ücretleri de daha yüksektir (Katz, 2016).

\section{TÜRKİYE'DE ENERJİ SÜBVANSİYONLARI}

Türkiye'de sera gazı emisyonu (CO2) TÜIK verilerine göre 2018 yılında toplam sera gazı emisyonu 1990 yılına göre \% 137,5 artmıştır. gider artmaktadır. Benzer şekilde kişi başına düşen sera gazı emisyonu 1990'da 3,88 iken 2016 yılında yaklaşık iki katı artarak 6,3' yükselmiştir (TUIK, 2020). Yine sera gazı emisyonuna neden olan fosil yakıt üretimi 2008-2016 döneminde dokuz katın üzerinde artış gerçekleşmiştir. Yine Türkiye OECD üye ülkeleri arasında en yüksek sera gazı emisyon artışına sahiptir (OECD, 2019b: 116). Türkiye 2018 sera gazı emisyonlarının, yaklaşık \%71'i enerji üretiminde kullanılan yakıt tüketimlerinden kaynaklanmaktadır (OECD, 2019b: 25). Bu gerçekler nedeniyle Türkiye 1992 Birleşmiş Milletler Biyolojik Çeşitlilik 


\section{Enerji Sübvansiyonlarının Etkileri ve Türkiye Açısından Ampirik Bir Değerlendirmesi}

Sözleşmesiyle 2020 yılına kadar fosil yakıtlar da dâhil olmak üzere çevreye zararlı sübvansiyonları kaldıracağını taahhüt etmiştir (Doukas, Gençsü, 2019: 1). Ayrıca toplumun 1sınma ihtiyacı için doğal gaza geçirmeye ve kademeli olarak kömür sübvansiyonlarını kaldırmaya çalışmaktadır. Ülkedeki tüm illere 2018 yılı sonuna kadar doğal gaz hizmeti sunulmuştur. ${ }^{1}$ Bunun yanı sıra halen jeotermal ve güneş enerjisi ile isıtılan 120.000 hane ve sera olsa da, bu gibi alternatifler için verilen sübvansiyonların daha fazla kullanılması bir gerekliliktir (OECD, 2019b: 34). Zira Türkiye açısından 2020'de hem rüzgâr hem de güneş enerjisi santrali inşa etme maliyeti, aynı güce sahip yeni kömür santralleri inşa etmekten daha ucuzdur (Bridle, Kitson, 2014: 5)

Ülkemizde en önemli fosil yakıt sübvansiyonu, birçok sanayi sektöründe girdi olarak kullanılan yüksek emisyonlu bitüm ve petrol kok yakıtları ${ }^{2}$ ile ilgili gerçekleşmektedir (Şekil 1). Ayrıca yoksul ailelere 1sıtma için kömür yardımı doğrudan bütçe transferlerine neden olan en önemli sübvansiyon biçimini temsil etmektedir. Program için yapılan harcamalar 2008 yılında 443 milyon TL'den 2017'de 1,3 milyar TL'ye dayanmıştır (OECD, 2019b: 116; Yıldızhan, 2017: 1921; OECD, 2018). 2013 yılında Türkiye'de kömür sübvansiyonları, nominal GSYİH'nin \% 0,1'i civarında gerçekleşmiştir. Oransal olarak bu durum önemli görünmese de, mevcut yapının, benzer yeni politikalarla ivme kazanması, ülkeyi kömüre sıkı sıkıya bağlı teknik, kurumsal ve hukuki bir zemine oturturken temiz enerjilerin önünde ciddi engeller oluşturmaktadır (Acar vd., 2015). Nitekim uluslararası petrol fiyatlarındaki ve döviz kurlarındaki dalgalanmalar karşısında yakıt fiyatlarını dengelemek için 2018'de

1 2016-2019 arasında konutlarda toplam doğal gaz abone sayısı \% 21,2 artarak 15 milyon 861 bin civarına ulaşmıştır (Enerji Atlası). 2010-2019 arasında doğal gaz tüketimi \% 17,3 artarken bunun \% 32'si konutlarda gerçekleşmiştir (Enerji Piyasası Düzenleme Kurumu/EPDK, 2020: 68, 70).

2 Bitüm, belirli ham petrollerden (örneğin, Orta Doğu, Meksika veya Güney Amerika ham petrolünden) türetilen bir kalıntıdır. Genellikle yol yapımında, çatı kaplaması ve boru sızdırmazlığı veya kaplamada kullanılan asfaltı üretmek için diğer bileşenlerle (örneğin, çakılla) karıştırılır (Çevre ve Şehircilik Bakanlığı, 2012: .49). Ham petrolün rafine edilmesi sırasında ortaya çıkan bir yan üründür. Kullanım alanları; çimento fabrikaları, manyezit ve kireç işletmeleri, elektrik santralleri, demir-çelik ve alüminyum endüstrisinde kullanılır (Tamzok, 2014). 
yürürlüğe konan yeni bir düzenleme göz önüne alındığında fosil yakıt destekleri daha da artmıştır (Anatolian Agency (AA), 2018).

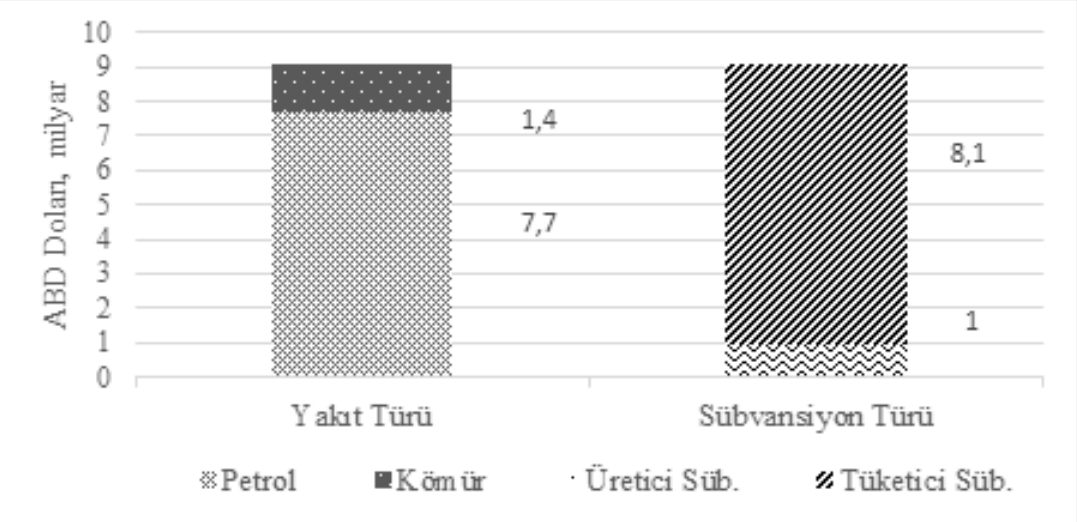

Not: 2010 sabit fiyatlara dönüştürmek için 2016 GSYH deflatörü ve satın alma gücü paritesi kullanılmıştır.

Kaynak: OECD, 2019b: 116.

Şekil 1: Türkiye'de Yakıt Cinsine ve Sübvansiyon Türüne Göre Toplam Sübvansiyonlar, 2016

Türkiye taş kömürü (linyit) bazlı elektrik üretimi açısından 2015 yılındaki büyüme oranıla OECD ülkeleri içinde beşinci sırada bulunmaktadır. Linyit tüketimi 2014 yılında ülke tarihinin en büyük iş kazası kabul edilen maden kazasının etkisiyle önceki yıla göre \% 30 düşmüştür. Bu durum kömür bazlı elektrik üretiminin de \% 4 azalmasına neden olmuştur (IEA, 2016: 20, 22). Hükümet, fosil yakit kullanımını desteklemenin yanı sıra kömür üretimine de destek sağlıyor. Örneğin, devlete ait Türk Taş Kömür İşletmelerinin taş kömürü üretim maliyetleri 2013 yılında ton başına ortalama $619 \mathrm{TL}$ iken, ortalama satış fiyatı 194 TL olup maliyetin sadece üçte biri idi. Taşkömürü üretim maliyetleri 2017 yılında ton başına 1.347 TL'dir. Ortalama satış fiyatı ise sadece 309 TL'dir ve aradaki farkı hazine finanse etmiştir. Devletin ton başına verdiği destek 2013'ten 2017'ye kadar 3,2 katından 4,4 katına çıkmıstır. Taşkömürüne 2017 yılındaki toplam destek ise 896 milyon TL olarak gerçekleşmiştir. Ayrıca 2.089 milyon yoksul aileye ayni kömür yardımı yapılmıştır (OECD, 2019c: 3). Yoksul ailelere kömür sağlanması, fosil yakıtların konut 1sıtması 


\section{Enerji Sübvansiyonlarının Etkileri ve Türkiye Açısından Ampirik Bir Değerlendirmesi}

için kullanımını teşvik eder ve kapalı mekân hava kalitesi açısından olumsuz sağlık etkilerine, ${ }^{3}$ yerel hava kirliliğine ve sera gazı emisyonlarının artmasına neden olur.

Türkiye enerji ihtiyacının karşılanmasında 1990 yılında \% 50 olan ithal bağımlılığı günümüzde, \% 75'e dayanmıştır. ${ }^{4} \mathrm{Bu}$ da 2018 yılında 43, 2019 yılında 41 milyar dolar döviz çıkışına neden olmaktadır (Kaytazoğlu vd., 2020; BBC, 2020). Bu nedenle, ithal yakit kaynaklarına bağımlılı̆̆ın azaltılmasına yardımcı olmak için 2010 yılından bu yana petrol, doğal gaz ve kömür arama faaliyetleri desteklenmektedir (OECD, 2019c: 3).

Fakat ülkemizin benimsediği enerji arz güvenliği politikası çerçevesinde verilen fosil yakıt (kömür üretim) teşvikleri, ulusal ve küresel değişkenler birlikte değerlendirildiğinde beklenenin aksine bazı soru işaretlerini gündeme getirmektedir. Enerji güvenliğinin yerli kömür üretimiyle sağlanacağı düşüncesi bazı koşullar altında gerçeği yansıtmayabilir. Bunun için öncelikle ulusal rezervlerin iç talebi karşılayabilmesi gerekmektedir. Fakat Türkiye'de kömür üretimi genellikle düşük kalorili linyit şeklindedir. Yurtiçi enerji talebi tahminlerine göre, bilinen rezervler sadece 2050 yılına kadar yeterli olacaktır. Bu tarihten sonra da faydalı ömrü devam eden kömüre dayalı kurulu elektrik santralleri ise, atıl kalacağından yatırım maliyetlerinin bir kısmı heba olacaktır. Aynı zamanda maden çıkarma işlemleri, madenleri ithal kaynaklardan elde etmekten daha ucuza gerçekleşip gerçekleşmediği enerji arz güvenliğini etkileyen bir diğer faktördür. Bu noktada yurtiçi maliyetleri belirleyen önemli bir unsur da uluslararası enerji fiyatlarıdır. 2020 yılında salgın hastalıkla birlikte küresel ekonominin durma noktasına gelmesi ile petrol fiyatları dip seviyeleri görmüştür. ${ }^{5}$ Petrol ve doğal gaz fiyatlarında gözlenen

32016 verilerine göre, iç mekân hava kirliliğine bağlı olarak dünyada her yıl 3,8 milyon erken ölüm yaşanmaktadır. Dünyada görülen felç vakalarının $\%$ 18'i, kalp hastalıklarının \% 27'si, kronik akciğer rahatsızlıklarının \% 20 'si, akciğer kanserlerinin \% 8'i ve akciğer iltihaplanmasının \% 27'si aynı sebeple ortaya çıkmaktadır (WHO, 2018).

4 Bu oranın da, 4.5211,47 milyon $\mathrm{Sm}^{3}$ miktarla, üçte biri doğal gaz ithalatı için yapılmaktadır (EPDK, 2020; 10; NTV, 2020).

5 Uluslararası enerji fiyatlarının düşmesi bunlar üzerinde uygulanan yakıt sübvansiyonlarının baskısını da bir nebze azaltmıştır. 
düşüşler kömüre alternatif enerji kaynaklarını ucuzlatarak Türkiye'nin kömür madeni konusunda sahip olduğu üstünlüklerini törpüleyebilir. Sonuçta, enerji üretiminde ithal kaynaklara bağımlılığa neden olacağı için hem cari açı sorunu hem de uluslararası enerji fiyatlarına karşı kırılganlıkların devam etmesine neden olabilir (Acar vd., 2015: 21-22).

Yapılan genel denge analizleri sonucunda Türkiye'de kömüre sağlanan üretim ve yatırım sübvansiyonlarının kaldırılması, 2030 yılına kadar CO2 emisyonlarında hem yüksek hem de düşük gelirli bölgelerde kömür kullanımından kaynaklanan $\mathrm{CO} 2$ emisyonlarını yaklaşık \% 42 seviyesinde azalacaktır. Bu senaryoya göre, 2030'da, ülke çapında genel emisyonlarda da \% 5,4'lük bir düşüş beklenmektedir. Enerjiyle ilgili ortaya çıkan $\mathrm{CO} 2$ emisyonlarında toplam azalma ise, 42,5 milyon tona ulaşmaktadır ve enerjiden kaynaklı CO2' nin GSYİH'ye oranı $0.322 \mathrm{~kg} /$ dolar daha azalacaktır. Yani her 1 dolarlık üretimin neden olduğu emisyonlar 0,322 kg daha düşük gerçekleşecektir. Buna karşın kömür sübvansiyonlarının kaldırılması GSYİH'de neden olacağı kayıp sadece \% 0,5'tir ve diğer sektörlere doğru kaynak dağılımı üzerindeki olumlu ikame etkilerinin baskın olduğu görülmektedir (Acar, Yeldan, 2016: 13).

Türkiye Madencilik ve Taşocağı sektöründe istihdam edilen kişi 1998 yılında 229.000 iken, Şubat 2015'te 117.000 kişiye düşmüştür. Aynı dönemde sektörün toplam istihdam içindeki payı \% 1,3'ten \% 0,7'ye gerilemiştir (IPC, 2016: 32). Kömür sübvansiyonlarının kaldırılması, kömür temelli sektörlerde istihdamın azalması sonucunu doğuracağından olası istihdam kayıplarının telafisi ve yan etkilerin hafifletilmesine yönelik politikalarla eşgüdümlü uygulanmalıdır. Bu nedenle fosil yakıt tüketim sübvansiyonlarının kaldırılması, yoksul ailelere ve ekonominin genelinde daha temiz alternatiflere geçiş desteği eşliğinde, aşamalı olarak yapılmalıdır. Maliyet-fayda analizlerinin geliştirilmesi, bütün büyük altyapı yatırımlarında olduğu gibi enerji altyapı yatırımlarında da sağlanmalıdır. Böylelikle kamu desteğine olan ihtiyaç en aza indirilebilir (OECD, 2019c: 121133). 


\section{AMPİRIK ANALİZ}

Çalışmanın analizi içeren bu bölümünde, Türkiye'de de enerji sübvansiyonlarının çevresel, ekonomik ve sosyal etkilerini incelenecektir.

\subsection{Veri ve Metodoloji}

Analizde kullanılan değişkenler; enerji sübvansiyonlar, CO2 emisyonu, Gayrisafi Yurtiçi Hasıla ve İşsizlik oranıdır. Bu değişkenlere ilişkin 1990-2018 yılı veriler OECD’den alınmıştır. enerji sübvansiyonlarının çevresel, ekonomik ve sosyal etkileri 1990-2018 dönemi verileri kullanılarak ARDL eştümleşme analizi ve TodaYamamoto nedensellik analizi uygulanacaktır. Öncelikle birim kök testi uygulanmaktadır. Daha sonra ARDL modeli ve sinır testi yapılmıştır.

\subsection{Analiz Uygulamas1}

Ekonometrik analizde öncelikle değişkenlerin durağanlık düzeylerinin belirlenmesi gerekmektedir. $\mathrm{Bu}$ amaçla çalışmada kullanılan değişenlere birim kök testleri uygulanmıştır. Ancak birim kök testi sonuçlarına geçmeden önce her bir seri için kullanılacak model yapısı ve gecikme uzunlukları hakkında bilgi vermekte yarar vardır. Birim kök sınamasında kullanılacak modelde deterministik bileşenlerin (kesme ve/veya trend) olup olmaması hiyerarşik bir süreçle belirlenmiştir. Buna göre; Sübvansiyon miktarı $\left(\mathrm{SBV}_{\mathrm{t}}, \mathrm{TL}\right)$ değişkeninde kesmeli ve trendli modelin uygun olduğu belirlenmiştir. İşsizlik Oranı $\left(\mathrm{UNEMP}_{\mathrm{t}}, \%\right)$ değişkeni için kesmeli ve trendsiz model uygun bulunmuştur. Kişi başına GSYİH $\left(\mathrm{GDP}_{\mathrm{t}}, \mathrm{TL}\right)$ ve CO2 Emisyonu $\left(\mathrm{CO}_{\mathrm{t}}\right.$, Milyon Ton) değişkeni için ise kesmesiz ve trendsiz modelin uygun olduğu görülmektedir. İkinci olarak kalıntıların temiz-dizi olup olmadığını belirlemek amacıyla modele eklenmesi gereken gecikme sayısı ise AIC ve SIC bilgi kriterleri ile seçilmiştir. Buna göre birim kök testi sonuçları Tablo 1'de sunulmaktadır. 
Tablo 1: Kırılmasız Birim Kök Testi Sonuçları

\begin{tabular}{|c|c|c|c|}
\hline Değişkenler & ADF & PP & ADF-GLS \\
\hline $\mathrm{SBV}_{\mathrm{t}}$ & $-3,1194$ & $-3,1473$ & $-3,1152^{*}$ \\
\hline$\Delta \mathrm{SBV}_{\mathrm{t}}$ & $-8,2949^{* * *}$ & $-8,2949^{* \star *}$ & $-8,6074^{\star * \star}$ \\
\hline $\mathrm{CO}_{\mathrm{t}}$ & 3,8147 & 10,6307 & - \\
\hline$\Delta \mathrm{CO}_{2}$ & $-3,8981^{* * *}$ & $-3,8981^{* * *}$ & - \\
\hline $\mathrm{GDP}_{\mathrm{t}}$ & 4,0516 & 5,4233 & - \\
\hline$\Delta \mathrm{GDP}_{\mathrm{t}}$ & $-3,3596^{* * *}$ & $-3,3643^{* * *}$ & - \\
\hline UNEMP $_{\mathrm{t}}$ & $-2,3899$ & $-1,7227$ & $-2,3816^{* *}$ \\
\hline$\triangle \mathrm{UNEMP}_{\mathrm{t}}$ & $-4,3355^{* * *}$ & $-4,3646^{* * *}$ & $-4,4216^{* * *}$ \\
\hline
\end{tabular}

Not: * \%10 düzeyinde anlamlıdır, ** \%5 düzeyinde anlamlıdır, *** \%1 düzeyinde anlamlıdır.

Tablo 1 incelendiğinde Sübvansiyon $\left(\mathrm{SBV}_{\mathrm{t}}\right), \mathrm{CO} 2$ emisyonu $\left(\mathrm{CO}_{\mathrm{t}}\right)$, Gayrisafi Yurtiçi Hasıla $\left(\mathrm{GDP}_{\mathrm{t}}\right)$ ve İşsizlik oranı $\left(\mathrm{UNEMP}_{\mathrm{t}}\right)$ değişkenlerinin; ADF, PP ve ADF-GLS birim kök testlerine göre durağan-dişı olduğu görülmektedir. Bu serilerin birinci dereceden farkları alındığında ise durağanlaşmışlardır.

Durağan-dışı değişkenlerin, durağan-dışı olmasının sebeplerinden birisi meydana gelen şokların serilerin veri üretme sürecinin değişmesine neden olabilmesidir. Diğer bir ifadeyle eğer yapısal kırılma varken, göz ardı edilirse seriler durağan-dışı eğiliminde olacaktır. O halde ADF, PP ve ADF-GLS birim kök testleri yapısal kırılmayı dikkate almadıkları için bu testlerden elde edilen sonuçlar yetersiz olacaktır. Bu nedenle bu aşamada durağan-dışı bulunan $\mathrm{SBV}_{\mathrm{t}}$, $\mathrm{CO}_{\mathrm{t}}, \mathrm{GDP}_{\mathrm{t}}$ ve $\mathrm{UNEMP}_{\mathrm{t}}$ serilerine kırılmalı birim kök testleri uygulanmiştır. 
Enerji Sübvansiyonlarının Etkileri ve Türkiye Açısından

Ampirik Bir Değerlendirmesi

Tablo 2: Kırılmalı Birim Kök Testi Sonuçları

\begin{tabular}{|l|c|c|c|}
\hline Değişkenler & Perron & Lee-Strazicich & Lumsdaine-Papell \\
\hline \multirow{2}{*}{$\mathrm{SBV}_{\mathrm{t}}$} & $\begin{array}{c}-8,1614^{* * *} \\
(2005)\end{array}$ & - & - \\
\hline \multirow{2}{*}{$\mathrm{CO} 2_{\mathrm{t}}$} & $-3,7587$ & $-6,5888$ & $-4,4721$ \\
& $(2014)$ & $(2010)$ & $(2003,2015)$ \\
\hline \multirow{2}{*}{$\mathrm{GDP}_{\mathrm{t}}$} & $-3,8170$ & $-9,4849^{* * *}$ & - \\
\hline \multirow{2}{*}{ UNEMP $_{\mathrm{t}}$} & $(2001)$ & $(2010)$ & - \\
\hline
\end{tabular}

Not:* \%10 düzeyinde anlamlıdır, ** \%5 düzeyinde anlamlıdır, *** \%1 düzeyinde anlamlıdır.

Tablo 2'de uygulanan yapısal kırılmalı birim kök testlerinden ilki Perron (1997) sinamasidir. Perron (1997) sinamasında elde edilen sonuçlar incelendiğinde Sübvansiyon destekleri ve işsizlik oranı değişkenlerinin yapısal kırılma sebebiyle durağan dışı olduğu sonucuna ulaşılmaktadır. Diğer bir ifadeyle serilerin durağan-dışı olmasının sebebi yapısal kırılmadır. Yapısal kırılma dikkate alındığında ise her iki serinin durağan olduğu görülmektedir. Ancak CO2 emisyonları için uygulana Perron (1997) sınaması sonucunda yine serinin durağan dişı olduğu görülmektedir (Perron, 1997: 355385). Bu nedenle Tablo 2'nin ikinci ve üçüncü sütunlarında iki kırılmalı yapıyı dikkate alan yapısal kırılmalı birim kök testleri ele alınmaktadır. Gerek Lumsdaine-Papell (1997) gerekse Lee-Strazicich (2003, 2004), zaman serilerinde iki kırılma varken, tek kırılma alınmasının yanlı sonuçlar vereceğini ortaya koymaktadırlar. Buna göre elde edilen sonuçlar incelendiğinde her iki kırılmalı birim kök sınaması da CO2 emisyonu serisi için Lumsdaine-Papell (1997) testi iki kırılma olduğunu Lee-Strazicich $(2003,2004)$ ise tek kırılma olduğunu göstermektedir. Ancak her iki yapısal kırılma testi sonucunda $\mathrm{CO} 2$ emisyonu serisinin durağan-dışı olduğu görülmektedir. Diğer bir ifadeyle CO2 emisyonunun durağan dış1 olmasının sebebi yapısal kırılma değildir. Son olarak GDP serisinde ise Lee-Strazicich (2004) yapısal kırılmalı birim kök testi sonucunda tek kırılma etrafında serinin durağan olduğu görülmektedir (Lumsdaine, Papell, 1997: 212-218; Lee, Strazicich, 2003: 1082-1089; Lee, Strazicich, 2004). Buna göre yapısal kırılmasız ve yapısal kırılmalı birim kök testleri sonuçları genel olarak incelendiğinde $\mathrm{CO} 2$ 
emisyonu dışındaki serilerin yapısal kırılmalar etrafında durağan olduğu söylenebilmektedir.

\subsection{Eştümleşme Sonuçları}

Değişkenlerin farklı mertebeden durağan olmaları, sebebiyle Pesaran vd. (2001)' in ARDL sinir testi kullanilabilmektedir (Pesaran vd., 2001: 289-326). Buna göre genel yapıda ARDL modeli şu şekildedir:

\section{gos} Değişkenler arasında eştümleşme olup olmadığını belirlemek amacıyla eştümleşme yoktur sıfır hipotezi şu şekilde kurulmaktadır:

$\mathrm{H}_{0}: \beta_{1}=\beta_{2}=0$

$\mathrm{H}_{1}: \beta_{1} \neq \beta_{2} \neq 0$

Burada hesaplanan F-istatistiği sonucunda, Pesaran vd. (2001)'deki kritik değerler ile karşılaştırılır. Pesaran vd. kritik değerleri I(0) ve I(1) çerçevesinde alt ve üst sınırı yansıtacak şekilde oluşturmuşlardır. Eğer hesaplanan değer üst sınırı gösteren kritik değerlerden büyük ise sıfır hipotezi reddedilerek değişkenlerin eştümleşik olduğu sonucuna ulaşılır. Fakat hesaplanan değer alt sınırdan küçük ise eştümleşmenin olmadığı, alt ve üst sınır arasında ise kararsızlık söz konusu olacaktır.

\subsubsection{ARDL Modeli ve Sınır Testi}

Sınır testi ile değişkenler arasında uzun dönemli bir ilişki olduğu tespit edildikten sonra, ilgili değişkenler arasındaki uzun dönemli ilişkileri göstermek amacıyla uzun dönemli ARDL modeli tahmini aşağıda gösterilmektedir. 


\section{Enerji Sübvansiyonlarının Etkileri ve Türkiye Açısından}

Ampirik Bir Değerlendirmesi

$\Delta \mathrm{Y}_{\mathrm{t}}=\alpha_{0}+\sum_{\mathrm{j}=1}^{\mathrm{p}} \alpha_{1 j} \Delta \mathrm{Y}_{\mathrm{t}-\mathrm{j}}+\sum_{\mathrm{j}=0}^{\mathrm{p}} \alpha_{2 \mathrm{j}} \Delta \mathrm{X}_{\mathrm{t}-\mathrm{j}}+\beta_{1} \mathrm{Y}_{\mathrm{t}-1}+\beta_{2} \mathrm{X}_{\mathrm{t}-1}+\mathrm{u}_{\mathrm{t}}$

Burada yine gecikme uzunluğu p'nin bulunması için bilgi kriterleri kullanılmaktadır. Buna göre tahmin edilen uzun dönem ARDL modeli Tablo 3'te gösterilmektedir.

Tablo 3: ARDL Modeli Tahmin Sonuçları

\begin{tabular}{|c|c|c|c|}
\hline & $\mathrm{CO}_{\mathrm{t}}(\mathrm{ARDL}(1,4))$ & $\mathrm{GDP}_{\mathrm{t}}(\operatorname{ARDL}(8,7))$ & $\operatorname{UNEMP}_{\mathrm{t}}(\operatorname{ARDL}(6,7))$ \\
\hline KESME & $\begin{array}{l}48,35110^{* *} \\
(18,36967)\end{array}$ & \begin{tabular}{|l|}
$-3501,285$ \\
$(3111,334)$ \\
\end{tabular} & $\begin{array}{l}-8,696697 \\
(7,227326) \\
\end{array}$ \\
\hline $\mathrm{CO} 2_{\mathrm{t}-1}$ & $\begin{array}{l}0,705138^{* * *} \\
(0,117805)\end{array}$ & & \\
\hline $\mathrm{GDP}_{\mathrm{t}-1}$ & & $\begin{array}{l}0,032912 \\
(0,545627)\end{array}$ & \\
\hline $\mathrm{GDP}_{\mathrm{t}-2}$ & & \begin{tabular}{|l|}
0,719248 \\
$(0,555904)$
\end{tabular} & \\
\hline $\mathrm{GDP}_{\mathrm{t}-3}$ & & \begin{tabular}{|c|}
$-0,099262$ \\
$(0,359248)$
\end{tabular} & \\
\hline $\mathrm{GDP}_{\mathrm{t}-4}$ & & $\begin{array}{l}-0,171465 \\
(0,355337)\end{array}$ & \\
\hline $\mathrm{GDP}_{\mathrm{t}-5}$ & & $\begin{array}{l}0,187828 \\
(0,329733)\end{array}$ & \\
\hline $\mathrm{GDP}_{\mathrm{t}-6}$ & & $\begin{array}{l}0,235154 \\
(0,401048)\end{array}$ & \\
\hline $\mathrm{GDP}_{\mathrm{t}-7}$ & & $\begin{array}{l}0,110657 \\
(0,423891)\end{array}$ & \\
\hline $\mathrm{GDP}_{\mathrm{t}-8}$ & & $\begin{array}{l}0,393138 \\
(0,477988)\end{array}$ & \\
\hline UNEMP $_{\mathrm{t}-1}$ & & & $\begin{array}{l}0,680840 \\
(0,362831)\end{array}$ \\
\hline $\mathrm{UNEMP}_{\mathrm{t}-2}$ & & & \begin{tabular}{|l|}
0,448821 \\
$(0,449844)$
\end{tabular} \\
\hline $\mathrm{UNEMP}_{\mathrm{t}-3}$ & & & $\begin{array}{l}0,303300 \\
(0,415212)\end{array}$ \\
\hline $\mathrm{UNEMP}_{\mathrm{t}-4}$ & & & $\begin{array}{l}-0,003402 \\
(0,332481)\end{array}$ \\
\hline $\mathrm{UNEMP}_{\mathrm{t}-5}$ & & & $\begin{array}{l}0,625775^{* * *} \\
(0,320234)\end{array}$ \\
\hline $\mathrm{UNEMP}_{\mathrm{t}-6}$ & & & $\begin{array}{l}0,067248 \\
(0,326465)\end{array}$ \\
\hline
\end{tabular}




\begin{tabular}{|c|c|c|c|c|}
\hline & Tablo 3. (Dev & & & \\
\hline & $\mathrm{SBV}_{\mathrm{t}}$ & $\begin{array}{l}5,52 \mathrm{E}-08^{* *} \\
(2,51 \mathrm{E}-08)\end{array}$ & $\begin{array}{l}5,10 \mathrm{E}-07 \\
(2,36 \mathrm{E}-06)\end{array}$ & \begin{tabular}{|l|}
$-3,39 \mathrm{E}-10$ \\
$(2,58 \mathrm{E}-09)$
\end{tabular} \\
\hline & $\mathrm{SBV}_{\mathrm{t}-1}$ & \begin{tabular}{|l|}
$3,85 \mathrm{E}-08$ \\
$(3,00 \mathrm{E}-08)$ \\
\end{tabular} & \begin{tabular}{|l}
$-1,39 \mathrm{E}-07$ \\
$(1,97 \mathrm{E}-06)$
\end{tabular} & $\begin{array}{l}5,37 \mathrm{E}-09^{* * *} \\
(2,65 \mathrm{E}-09)\end{array}$ \\
\hline & $\mathrm{SBV}_{\mathrm{t}-2}$ & $\begin{array}{l}-8,41 \mathrm{E}-08^{* *} \\
(3,22 \mathrm{E}-08)\end{array}$ & $\begin{array}{l}-2,81 \mathrm{E}-06 \\
(2,08 \mathrm{E}-06)\end{array}$ & $\begin{array}{l}7,52 \mathrm{E}-09^{* *} \\
(3,03 \mathrm{E}-09)\end{array}$ \\
\hline & $\mathrm{SBV}_{\mathrm{t}-3}$ & $\begin{array}{l}1,47 \mathrm{E}-08 \\
(3,11 \mathrm{E}-08)\end{array}$ & $\begin{array}{l}-1,25 \mathrm{E}-07 \\
(2,18 \mathrm{E}-06)\end{array}$ & \begin{tabular}{|l|}
$4,13 \mathrm{E}-10$ \\
$(5,20 \mathrm{E}-09)$
\end{tabular} \\
\hline 404 & $\mathrm{SBV}_{\mathrm{t}-4}$ & $\begin{array}{l}6,69 \mathrm{E}-08^{* *} \\
(2,99 \mathrm{E}-08)\end{array}$ & \begin{tabular}{|l|}
$4,35 \mathrm{E}-06$ \\
$(2,08 \mathrm{E}-06)$ \\
\end{tabular} & $\begin{array}{l}-1,85 \mathrm{E}-08^{* *} \\
(6,10 \mathrm{E}-09)\end{array}$ \\
\hline IJSI 14/2 & $\mathrm{SBV}_{\mathrm{t}-5}$ & & \begin{tabular}{|l|}
$4,45 \mathrm{E}-06$ \\
$(2,83 \mathrm{E}-06)$
\end{tabular} & \begin{tabular}{|l}
$-9,09 \mathrm{E}-09$ \\
$(6,69 \mathrm{E}-09)$
\end{tabular} \\
\hline $\begin{array}{r}\text { Aralık } \\
\text { December } \\
2021\end{array}$ & $\mathrm{SBV}_{\mathrm{t}-6}$ & & $\begin{array}{l}-2,55 \mathrm{E}-06 \\
(2,07 \mathrm{E}-06)\end{array}$ & $\begin{array}{l}3,50 \mathrm{E}-09 \\
(4,19 \mathrm{E}-09)\end{array}$ \\
\hline & $\mathrm{SBV}_{\mathrm{t}-7}$ & & $\begin{array}{l}-3,32 \mathrm{E}-06 \\
(3,14 \mathrm{E}-06)\end{array}$ & $\begin{array}{l}4,57 \mathrm{E}-09 \\
(4,20 \mathrm{E}-09)\end{array}$ \\
\hline & Diagnostik İstati & tikler & & \\
\hline & $\mathrm{R}^{2}$ & 0,982 & 0,995 & 0,921 \\
\hline & $\overline{\mathrm{R}^{2}}$ & 0,976 & 0,973 & 0,764 \\
\hline & DW & 2,106 & 2,8133 & 2,367 \\
\hline & F-istatistiği & $161,367^{* * *}$ & $46,081^{* * *}$ & $5,8544^{* *}$ \\
\hline & Breusch-Godfrey & 0,0695 & 2,8817 & 3,6647 \\
\hline & Jarque-Bera & 0,0911 & 0,7396 & 0,1957 \\
\hline & White & 0,9668 & 1,4907 & 1,1525 \\
\hline & $\mathrm{ARCH}(1)$ & 0,6527 & $4,5830^{* *}$ & $11,2398^{* * *}$ \\
\hline & $\mathrm{ARCH}(2)$ & 0,7539 & 0,4156 & $8,2023^{* * *}$ \\
\hline
\end{tabular}

Not: $^{*} \% 10$ düzeyinde anlamlıdır, ${ }^{* *} \% 5$ düzeyinde anlamlıdır, ${ }^{* * *} \% 1$ düzeyinde anlamlidir.

İlk olarak Tablo 3'te tahmin edilmiş olan ARDL modellerinin normallik, otokorelasyon ve heteroskedastisiti gibi testlerin sonucunda genel olarak uygun oldukları görülmektedir. Buna göre Enerji sübvansiyonları ile CO2 emisyonları, GDP ve işsizlik oranları için hesaplanan Sınır testi F-istatistik sonuçları Tablo $4^{\prime}$ te verilmektedir: 
Tablo 4: Sınır Testi Sonuçları

\begin{tabular}{|l|c|c|c|c|c|}
\hline \multicolumn{2}{|l|}{ Endojen Değişken: $\mathbf{S B V}_{\mathbf{t}}$} & \multicolumn{3}{|l|}{ \%1 Kritik Değerler } & \multicolumn{2}{l|}{ \%5 Kritik Değerler } \\
\hline $\begin{array}{l}\text { Ekzojen } \\
\text { Değişken }\end{array}$ & F-istatistiği & $\mathbf{I}(\mathbf{0})$ & $\mathbf{I}(\mathbf{1})$ & $\mathbf{I}(\mathbf{0})$ & $\mathbf{I}(\mathbf{1})$ \\
\hline $\begin{array}{l}\text { CO2 } \\
\text { (ARDL(1,4)) }\end{array}$ & $4,8952^{*}$ & 4,94 & 5,58 & 3,62 & 4,16 \\
\hline $\begin{array}{l}\text { GDP }_{\mathrm{t}} \\
(\mathrm{ARDL}(8,7))\end{array}$ & 2,0987 & 4,94 & 5,58 & 3,62 & 4,16 \\
\hline $\begin{array}{l}\text { UNEMP } \\
(\mathrm{ARDL}(6,7))\end{array}$ & 1,0654 & 4,94 & 5,58 & 3,62 & 4,16 \\
\hline
\end{tabular}

Not: * \%5 düzeyinde anlamlıdır.

Tablo 4 incelendiğinde hesaplanan F-istatistik değeri $\mathrm{CO}_{\mathrm{t}}$ emisyonları için \% 5 anlamlılık düzeyinde fakat $\mathrm{GDP}_{\mathrm{t}}$ ve $\mathrm{UNEMP}_{\mathrm{t}}$ değişkenleri için ise \%1 anlamlılık düzeyinin üst sınır değerinden daha büyük bulunmuştur. Yani sıfır hipotezi red edileceği için ilgili değişkenler arasında uzun dönemli ilişki olduğu sonucuna ulaşılmaktadır.

ARDL modellerinden yararlanarak hesaplanan uzun dönem parametreleri ve standart hataları Tablo 5 'te sunulmaktadır.

Tablo 5: Uzun Dönem Katsayıları

\begin{tabular}{|l|l|l|l|}
\hline Değişkenler & Parametreler & Standart Hatalar & t-istatistiği \\
\hline KESME & $163,9787^{*}$ & 13,40198 & 12,23541 \\
\hline SBV $_{t}$ & $3,09 \mathrm{E}-07^{*}$ & $4,04 \mathrm{E}-08$ & 7,656735 \\
\hline
\end{tabular}

Not: * \%1 düzeyinde anlamlıdır.

CO2 modeli için uzun dönem katsayıları incelendiğinde değişkenlerin \% 1 anlamlılık düzeyinde istatistiksel olarak anlamlı olmadığ görülmektedir. Tahmin edilen parametrenin işaret ve büyüklügü incelendiğinde beklentiler yönünde pozitif bulunmuştur. Ancak parametrenin büyüklüğü sıfıra yakın olması uzun dönemde enerji sübvansiyonlarının çevresel etkilerinin zayıf düzeyde olduğunu göstermektedir. 


\subsubsection{Hata Düzeltme Modeli: ECM}

ARDL hata düzeltme modeli kısa dönem ve uzun dönem arasındaki ilişkileri ortaya koymak için önemli bir araçtır. Bu model şu şekilde sunulabilir:

$$
\Delta \mathrm{Y}_{\mathrm{t}}=\alpha_{0}+\sum_{j=1}^{\mathrm{p}} \alpha_{1 j} \Delta \mathrm{Y}_{\mathrm{t}-\mathrm{j}}+\sum_{\mathrm{j}=0}^{\mathrm{p}} \alpha_{2 j} \Delta \mathrm{X}_{\mathrm{t}-\mathrm{j}}++\gamma \mathrm{ECT}_{\mathrm{t}-1}+\mathrm{u}_{\mathrm{t}}
$$

Burada $\gamma$ kısa dönemde meydana gelecek bir dengesizliğin ne kadarının uzun dönemde giderileceğini gösteren katsayıdır. Ayrıca yine gecikme uzunluğu p'nin bulunması için bilgi kriterleri kullanılmaktadır. Buna göre hata düzeltme modeli Tablo 6 'da sunulmaktadir:

Tablo 6: ARDL Kısa Dönem ve Hata Düzeltme Modeli Sonuçları

\begin{tabular}{|l|c|c|c|}
\hline & Parametreler & Standart Hatalar & t-istatistiği \\
\hline$\Delta \mathrm{SBV}_{\mathrm{t}}$ & $5.52 \mathrm{E}-08^{*}$ & $2.18 \mathrm{E}-08$ & 2.532615 \\
\hline$\Delta \mathrm{SBV}_{\mathrm{t}-1}$ & $2.47 \mathrm{E}-09$ & $3.27 \mathrm{E}-08$ & 0.075588 \\
\hline$\Delta \mathrm{SBV}_{\mathrm{t}-2}$ & $-8.16 \mathrm{E}-08^{*}$ & $3.07 \mathrm{E}-08$ & -2.662344 \\
\hline$\Delta \mathrm{SBV}_{\mathrm{t}-3}$ & $-6.69 \mathrm{E}-08^{*}$ & $2.82 \mathrm{E}-08$ & -2.371484 \\
\hline $\mathrm{ECT}_{\mathrm{t}-1}$ & $-0.294862^{* *}$ & 0.072995 & -4.039458 \\
\hline \multicolumn{4}{|c|}{ Diagnostik İstatistikler } \\
\hline $\mathrm{R}^{2}$ & 0.515 & White & 0.7986 \\
\hline$\overline{\mathrm{R}}^{2}$ & 0.418 & ARCH(1) & 0.6527 \\
\hline DW & 2.106 & ARCH(2) & 0.7539 \\
\hline $\begin{array}{l}\text { Breusch- } \\
\text { Godfrey }\end{array}$ & 0.0712 & RESET(1) & 0.0017 \\
\hline Jarque-Bera & 0.0911 & RESET(2) & 1.1689 \\
\hline
\end{tabular}

Not: * \%5 düzeyinde anlamlıdır, ${ }^{* *} \% 1$ düzeyinde anlamlıdır.

Tahmin edilen hata düzeltme terimi beklendiği üzere negatif ve anlamlı bulunmuştur. Dolayısıyla bu durum Enerji sübvansiyonları ile $\mathrm{CO} 2$ emisyonları arasında kısa dönemde meydana gelecek bir dengesizliğin \% 29'unun bir sonraki dönemde düzeltildiği anlamına gelmekte ve bu düzelme her yıl tekrar etmektedir. 


\subsection{Toda-Yamamoto Nedensellik Testi Sonuçları}

Çalışmada değişkenler arasındaki nedensellik ilişkileri üzerinde durulurken, kullanılacak değişkenlerin durağanlık yapıları önem arz etmektedir. Zira durağan değişkenler için kullanılacak nedensellik testleri, durağan ve durağan-dışı değişkenler birlikte ele alındığında kullanılacak testler de farklılık göstermektedir. Tablo 1 ve Tablo 2 'de uygulanan birim kök testleri sonuçları değişkenlerden bazılarının durağan-dışı olduğunu ortaya koymaktadır. Toda-Yamamoto (1995) nedensellik testi değişkenlerin farklı dereceden entegre olması durumunda da fark almadan doğrudan değişkenlerin düzeyleri üzerinden uygulanabileceğini ortaya koymaktadır (Toda and Yamamoto, 1995: 225-250). Buna göre Tablo $7^{\prime}$ de enerji sübvansiyonları ile çevresel, ekonomik ve sosyal etkileri arasında nedensel ilişki olup olmadığı Toda-Yamamoto nedensellik testi çerçevesinde sunulmaktadır.

Tablo 7: Toda-Yamamoto Nedensellik Testi Sonuçları

\begin{tabular}{|l|c|c|c|c|}
\hline & $\mathrm{SBV}_{\mathrm{t}}$ & $\mathrm{CO2}_{\mathrm{t}}$ & $\mathrm{GDP}_{\mathrm{t}}$ & $\mathrm{UNEMP}_{\mathrm{t}}$ \\
\hline $\mathrm{SBV}_{\mathrm{t}}$ & - & $\begin{array}{c}6,0327^{* *} \\
(0,0140)\end{array}$ & $\begin{array}{c}0,0115 \\
(0,9147)\end{array}$ & $\begin{array}{c}3,5132^{*} \\
(0,0609)\end{array}$ \\
\hline $\mathrm{CO}_{\mathrm{t}}$ & $\begin{array}{c}0,6879 \\
(0,4173)\end{array}$ & - & - & - \\
\hline $\mathrm{GDP}_{\mathrm{t}}$ & $\begin{array}{c}0,1839 \\
(0,6680)\end{array}$ & - & - & - \\
\hline UNEMP $_{\mathrm{t}}$ & $\begin{array}{c}0,0544 \\
(0,8156)\end{array}$ & - & - & - \\
\hline
\end{tabular}

Not:* \%10 düzeyinde anlamlıdır, ** \%5 düzeyinde anlamlıdır.

Toda-Yamamoto nedensellik sonuçları incelendiğinde, Sübvansiyonlardan CO2 emisyonlarına doğru \% 5 düzeyinde, sübvansiyonlardan işsizlik düzeyine ise \%10 düzeyinde anlamlı bulunan bir nedensellik olduğu görülmektedir. Yine sübvansiyonlardan ekonomik büyümeye doğru nedensellik olduğu yönünde sonuçlara rastlanmamıştır. 


\section{SONUÇ}

Enerji kaynaklarının hem üretici hem de tüketicileri kapsayan geniş kullanım alanına sahip olma ve sınırlı doğal kaynak olmaları artan kamu müdahalesini gerektirmektedir. $\mathrm{Bu}$ müdahale araçlarının başında sübvansiyonlar gelir. Birçok ülke her yıl GSYİH'lerinin \% 5 veya daha fazlasını enerji sübvansiyonlarına ayırmaktadır. Sübvansiyonların sektörün gelişimini sağlamak ve enerji fiyatlarını belirli düzeylerde tutmak gibi amaçları gerçekleştirmek üzere getirilen kamu politikası araçları olmalarına rağmen bazı ekonomik, sosyal ve çevresel sorunlara neden oldukları görülmektedir. Bu olumsuz etkiler enerji sübvansiyonlarını dünya genelinde sorgulanır hale getirmiştir. Enerji elde etmek için de fosil yakıtlar dünyada en çok başvurulan doğal kaynaklardır. Fosil yakıtlardan kaynaklanan metan emisyonu tahminleri, üretimle orantılı olarak dönem boyunca artmıştır ve bu durum iklim değişikliği başta olmak üzere birçok çevresel sorunu beraberinde getirmektedir. Bu tür zararlı nitelik gösteren enerji kaynaklarının üretim ve tüketimini düşürmek üzere alınabilecek önlemlerin başında bu sektöre verilen sübvansiyonları kaldırmak veya azaltmaktır. Sübvansiyonların kaldırılmasının ekonomik faydaları fiyatlar, üretim yapısı ve uluslararası ticari faaliyetlerle açıklanabilse de gelişmekte olan ülkelerde ayrıca şeffaflık, hesap verilebilirlik, enerji arama, enerji üretimi ve enerji arzı için daha iyi yatırım kararları ve bunlar için daha verimli teknolojilerin kullanılması gibi mali ve teknolojik gelişim açısından da önem arz etmektedir.

Enerji sübvansiyonlarının yarattığı olumsuz etkiler farklı nitelikte olsa bile bu etkilerin birbiriyle bağlantılı olduğu görülmektedir. Nitekim çevresel ve yoksulluk üzerinde olumsuz etkileri telafi etme çabaları ekonomik ve mali dengeleri çok daha bozucu olabilmektedir.

Yapılan çalışmalar, enerji sübvansiyonunun kaldırılmasının bir çevre göstergesi olan sera gazı emisyonlarında çok önemli bir azalmaya ve ekonomik verimliliğin artmasına neden olacağını göstermektedir. Dolayısıyla enerji sübvansiyonlarının kaldırılması ekonomik büyüme, yoksullukla mücadele ve iklim değişikliğinin azaltılmasının önemli bir parçasıdır. Bu kapsamda dünya genelinde özellikle Almanya, ABD gibi ülkeler önemli adımlar atmışlardır. Ülkeler bazında bu konuda çalışmalar yapılmaktadır. Örneğin Çin için enerji sübvansiyonlarının kaldırılması ve bu şekilde elde edilecek kamu tasarrufunun çeşitli 


\section{Enerji Sübvansiyonlarının Etkileri ve Türkiye Açısından Ampirik Bir Değerlendirmesi}

kullanım alanlarına göre olası ekonomi ve çevresel kazanımları konusunda modeller oluşturulmuştur. Bu alanda yapılan çalışmalar değerlendirildiğinde enerji sübvansiyonlarının aşamalı olarak tamamen kaldırılması, küresel $\mathrm{CO} 2$ emisyonlarını yaklaşık olarak \% 5,8 azaltabilme potansiyeline sahip olabileceği görülmektedir. $\mathrm{Bu}$ çalışmada enerji sübvansiyonlarının çevresel, ekonomik ve sosyal etkilerini Türkiye uygulaması ile incelemektir. Bulgular, fosil yakıt kullanımının nispi olarak yüksek olduğu Türkiye açısından alınabilecek önlemler konusunda önemli olacaktır. Bu çalışmada da bahsedilen konular çerçevesinde Türkiye'deki enerji sübvansiyonlarını etkinliği analiz edilmiştir. Enerji sübvansiyonlarının aşamalı olarak tamamen kaldırılması, küresel CO2 emisyonlarını \%5,8 azaltabilme potansiyeline sahiptir. Bu ise iklim değişikliği politika hedeflerinin büyük bir kısmını oluşturmaktadır. Çalışmada enerji sübvansiyonlarının çevresel, ekonomik ve sosyal etkilerini ortaya koymak amaciyla 1990-2018 dönemi verileri kullanılarak ARDL eştümleşme analizi ve Toda-Yamamoto nedensellik analizi uygulanmıştır. Uygulanan analizler çerçevesinde enerji sübvansiyonları ile çevresel etkiler arasında uzun dönemde tek yönlü ilişki tespit etmiştir. Bu ilişki hem eştümleşme hem de nedensellik analizine göre zayıf düzeyde kalmakla birlikte sonuçlar genel olarak literatürle (Anderson, McKibbin, 1997) uyumludur. Hatta bazen \% 15'e varan emisyon azalması mümkün iken gelişmiş ülkelerde \% 1.5 artış görülebilmektedir. Bunun nedeni diğer ülkelerde sübvansiyonların kaldırılmasıyla azalan enerji tüketimi küresel pazara yönelerek enerji fiyatlarını düşürmesi yüksek enerji talebi olan gelişmiş ülkeleri daha da teşvik etmesidir

Ekonomik etkileri açısından bakıldığında, Toda-Yamamoto'ya göre sübvansiyonların ekonomik büyümeye bir etkisi olmadığına rastlanmıştır. Sadece eştümleşme analizi sonuçlarına bakıldığında ise, enerji sübvansiyonlarının uzun dönemli pozitif yönde bir ekonomik ilişkiye rastlanmamaktadır. Bu durum, Acar ve Yeldan (2016)'ın Türkiye için yaptıkları analiz sonuçlarıyla büyük benzerlik göstermektedir. Tersi sonuçlara ulaşılan çalışmalar da bulunmaktadır. Örneğin Burniaux ve J. Chanteau (2010) ve Lin ve Jiang (2011) tarafından yapılan çalışmalarında bu değişkenler arasında pozitif ilişki bulunmuştur. Politika oluştururken kısa vadeli hedefler tek kriter olmamalıdır. Olaylara kısa vadeli bir odaklanma, uzun vadeli ekonomik zararlar getirebilir. 


\begin{abstract}
Sosyal etkiler açısından, eştümleşme analizine göre enerji sübvansiyonlarının işsizlikle olan ilişkisi uzun dönemde anlamsız görülmektedir. Benzer sonuç başka çalışmalarda da görülmektedir. Örneğin OECD üyesi olmayan ülkelerde, sübvansiyonların kaldırılmasıyla çevresel ve enerji güvenliği hedeflerinden ziyade sosyal politika hedefleri daha çok desteklenmesine rağmen bu etkinin oldukça düşük olduğu görülmüştür. Bu bulgulara dayalı olarak Türkiye'de de enerji sübvansiyon politikalarından değişim yapılması gerektiği söylenebilir. Türkiye'de sübvansiyon politikalarında değişiklik yaparak çevreye olumlu etkide bulunulabilir. Klasik enerji sübvansiyonlarının yenilenebilir enerji ve enerji verimliliğine kaydırılması bile ekonomik etkinliği ve sosyal refahı da artırabilecektir. Bir yandan sübvansiyonların kaldırılması veya Aralı azaltılması diğer taraftan çevresel zararların azaltılmasının kamu December bütçesinde sağlayacağı tasarruflardan elde edilen gelir ile ilave kaynak sağlanabilecektir. Bu kaynakların eğitim, sağlık ve toplu konut gibi direk sosyal refah harcamalarında kullanılmasinın yoksullukla mücadele yaratacağı katkı uzun vadede GSYİH'yi de olumlu etkileyecektir.
\end{abstract}




\section{Enerji Sübvansiyonlarının Etkileri ve Türkiye Açısından Ampirik Bir Değerlendirmesi}

\section{KAYNAKÇA}

Acar, S.; Yeldan, E. (2016). “Environmental Impacts of Coal Subsidies in Turkey: A General Equilibrium Analysis”. Energy Policy, 90, 1-15.

Acar, S.; Kitson, L.; Bridle, R. (2015). “Subsidies to Coal and Renewable Energy in Turkey, Geneva: International Institute for Sustainable Development (IISD)", Global Subsidies Initiative Report.

Anatolian Agency (AA). “Turkey Gains Gas Find Worth $\$ 80$ Billion: IEA Head", 24 August 2020. https://www.aa.com.tr/en/energy/projects/turkeys-giant-gas-find-worth-80-billion-iea-head/30321 (Erişim Tarihi: 29.08.2020).

Anatolian Agency (AA). "Turkey to Stabilize Consumer Fuel Tax with New Rule", 17 May 2018. www.aa.com.tr/en/energy/transportation-fueloil/turkey-to-stabilize-consumer-fuel-tax-with-newrule/20091, (Erişim Tarihi: 13.05.2020).

Anderson, K.; McKibbin W. J. (1997). "Reducing Coal Subsidies and Trade Barriers: Their Contribution to Greenhouse Gas Abatement". University of Adelaide, Center for International Economic Studies (CIES), Seminar Paper, 97-07.

Arıkboğa, Ü. (2019). “Çevre Politikasının Ekonomik Araçları ve Türkiye'de Belediye Uygulamaları", Marmara Üniversitesi İktisadi ve İdari Bilimler Dergisi, 41(1), 23-50.

BBC News, “Karadeniz’de Bulunan Doğal Gaz Rezervi 405 Milyar Metreküpe Yükseldi", https://www.bbc.com/turkce/haberler-turkiye-54585247", (Erişim Tarihi: 09.01.2020).

Bridle, R.; Kitson, L., The Impact of Fossil-Fuel Subsidies on Renewable Electricity Generation. International Institute for Sustainable Development (IISD), 2014, http://www.iisd.org/sites/default/files/publications/impact-fossil-fuelsubsidies-renewable-electricity-generation.pdf, (Erişim Tarihi: 24.11.2020).

Burniaux, J. M.; Chanteau, J. (2010). Potential of Removing Fossil Fuel Subsidies: A General Equilibrium Assessment. Paris: OECD.

Burniaux, J. M.; Château, J.; Dellink, R.; Duval, R.; Jamet, S. (2009). “The Economics of Climate Mitigation: How to Build to Necessary Global Action in a Cost-Effective Manner", OECD Economics Department Working Papers, No. 701, Paris: OECD Publishing.

Carbon Tracker Initiative, Wind and Solar PV vs Coal (2020). London: https://carbontracker.org, (Erişim Tarihi: 25.11.2020).

Czako, V. (2020). Employment in the Energy Sector Status Report 2020, EUR 30186 EN, Luxembourg: Publications Office of the European Union. 


\section{Hakan AKAR, Filiz GİRAY, Mehmet ÇINAR}

Çevre ve Şehircilik Bakanlığı (2010). Petrol Rafinerileri için MET Kılavuzu, IPPC - Entegre Kirlilik Önleme ve Kontrol Eşleştirme Projesi TR 2008 IB EN 03, Faaliyet No: 2.1.4.d.3, Ankara.

Del Granado, J. A.; Coady, D.; Gillingham, R. (2010), “The Unequal Benefits of Fuel Subsidies: A Review of Evidence for Developing Countries", IMF Working Paper, Washington D.C.

Dickey, D. A.; Fuller, W.A. (1979). "Distribution of the Estimators for Autoregressive Time Series with a Unit Root". Journal of the American Statistical Association, 74, 427-431.

Dobbs, R.; Oppenheim, J.; Thompson, F.; Brinkman, M.; Zornes, M. (2011). Resource Revolution: Meeting The World's Energy, Materials, Food, and Water Needs, McKinsey Company. https://www.mckinsey.com/businessfunctions/sustainability/our-insights/resource-revolution\#, (Erişim Tarihi: 07.10.2020).

Doukas, A.; Gençsü, I. (2019). Turkey: G20 Coal Subsidies. Overseas Development Institute.

Elliott, G.; Rothenberg, T. J.; Stock, J. H.(1996). "Efficient Tests for an Autoregressive Unit Root". Econometrica, 64(4), 813-836.

Enerji Atlası. Türkiye Doğal Gaz Tüketimi, https://www.enerjiatlasi.com/ dogalgaz-tuketimi/, (Erişim Tarihi: 28.01.2021).

Enerji Piyasası Düzenleme Kurumu (EPDK) (2020). Doğal Gaz Piyasası 2019 Yılı Sektör Raporu. Ankara: Strateji geliştirme Daire Başkanlığı.

IEA (2018). World Energy Outlook 2018. Paris: OECD.

IEA (2016), Medium-Term Coal Market: Market Analysis and Forecasts to 2021. Paris: International Energy Agency.

IEA (2010). World Energy Outlook 2010. Paris: OECD.

IEA (2001). Coal Information. Paris: OECD.

IEA (1999). World Energy Outlook Insights, looking at Energy Subsidies: Getting the Prices Right. Paris: OECD.

IPC (2016). Coal Report: Turkey's Coal Policies Related to Climate Change, Economy and Health. Istanbul Policy Centre, Istanbul.

Katz, G. (2016). How Many Jobs Does Clean Energy Create?. https://www.greenbiz.com/article/how-many-jobs-does-clean-energycreate, (Erişim Tarihi: 25.12.2020).

Kaytazoğlu, O.; Tatlıcı, E.; Temel, E. (2020). “Doğal Gaz Bulundu: Karadeniz'deki Gaz Keşfi Türkiye'yi Nasıl Etkiler?", BBC, https://www.bbc.com/turkce/haberler-turkiye-53868045 (Erişim Tarihi: 22.08.2020). 


\section{Enerji Sübvansiyonlarının Etkileri ve Türkiye Açısından Ampirik Bir Değerlendirmesi}

Konrad, T. (2011). The Microeconomics of Green Jobs, Alt Energy Stocks, http://www.altenergystocks.com/archives/2011/10/the_microeconomics_of _green_jobs_1/. (Erişim Tarihi: 26.01.2021).

Lee, J.; Strazicich, M. C. (2003). “Minimum LM Unit Root Test with Two Structural Breaks". Review of Economics and Statistics, 85(4), 1082-1089.

Lee, J.; Strazicich, M. C. (2004). “Minimum LM Unit Root Test with One Structural Break", Appalachian State University Department of Economics Working Papers, No. 04-17.

Lin, B.; Jiang, Z. (2011). “Estimates of Energy Subsidies in China and Impact of Energy Subsidy Reform". Energy Economics, 33(2), 273-283.

Lumsdaine, R. L.; Papell, D. H. (1997). “Multiple Trend Breaks and the UnitRoot Hypothesis". The Review of Economics and Statistics, 79(2), 212-218.

NTV, Yeni Doğal Gaz Rezervi Türkiyénin Kaç Yıllık İhtiyacını Karşılayacak?, https://www.ntv.com.tr/ekonomi/yeni-dogalgaz-rezervi-turkiyenin-kacyillik-ihtiyacini-karsilayacak,aoYhC2LI1kWL4r2PBDiFVw. (Erişim Tarihi: 28.01.2021).

OECD (2019a). Economic Policy Reforms 2019: Going for Growth.

OECD (2019b). “OECD Environmental Performance Reviews: Turkey 2019”, OECD Environmental Performance Reviews, OECD Publishing, Paris. (Erişim Tarihi: 16.01.2021).

OECD (2019c). Fossil Fuel Support Country Note: Turkey, http://www.oecd.org /fossil-fuels/data/. (Erişim Tarihi: 14.05.2020).

OECD (2018). “OECD Analysis of Budgetary Support and Tax Expenditures, Turkey", OECD-IEA Fossil Fuel Support and Other Analysis, Paris: OECD Publishing.

OECD (2017a). Agricultural Policy Monitoring and Evaluation 2017. Paris: OECD Publishing.

OECD (2017b). Agriculture Statistics: Agricultural Support Estimates, https://www.oecd-ilibrary.org/agriculture-and-food/data/oecd-agriculturestatistics/agricultural-support-estimates-edition-2017_545b3853-en. (Erişim Tarihi: 14.01.2021).

OECD (2005a). Environmental Fiscal Reform for Poverty Reduction. Paris:

OECD (2005b). Environmentally Harmful Subsidies: Challenges for Reform. Paris:

Perron, P. (1997). "Further Evidence on Breaking Trend Functions in Macroeconomic Variables". Journal of Econometrics, 80(2), 355-385.

Pesaran, M. H.; Shin, Y.; Smith, R. J. (2001). “Bounds Testing Approaches to the Analysis of Level Relationships", Journal of Applied Econometrics, 16(3), 289326. 


\section{Hakan AKAR, Filiz GİRAY, Mehmet ÇINAR}

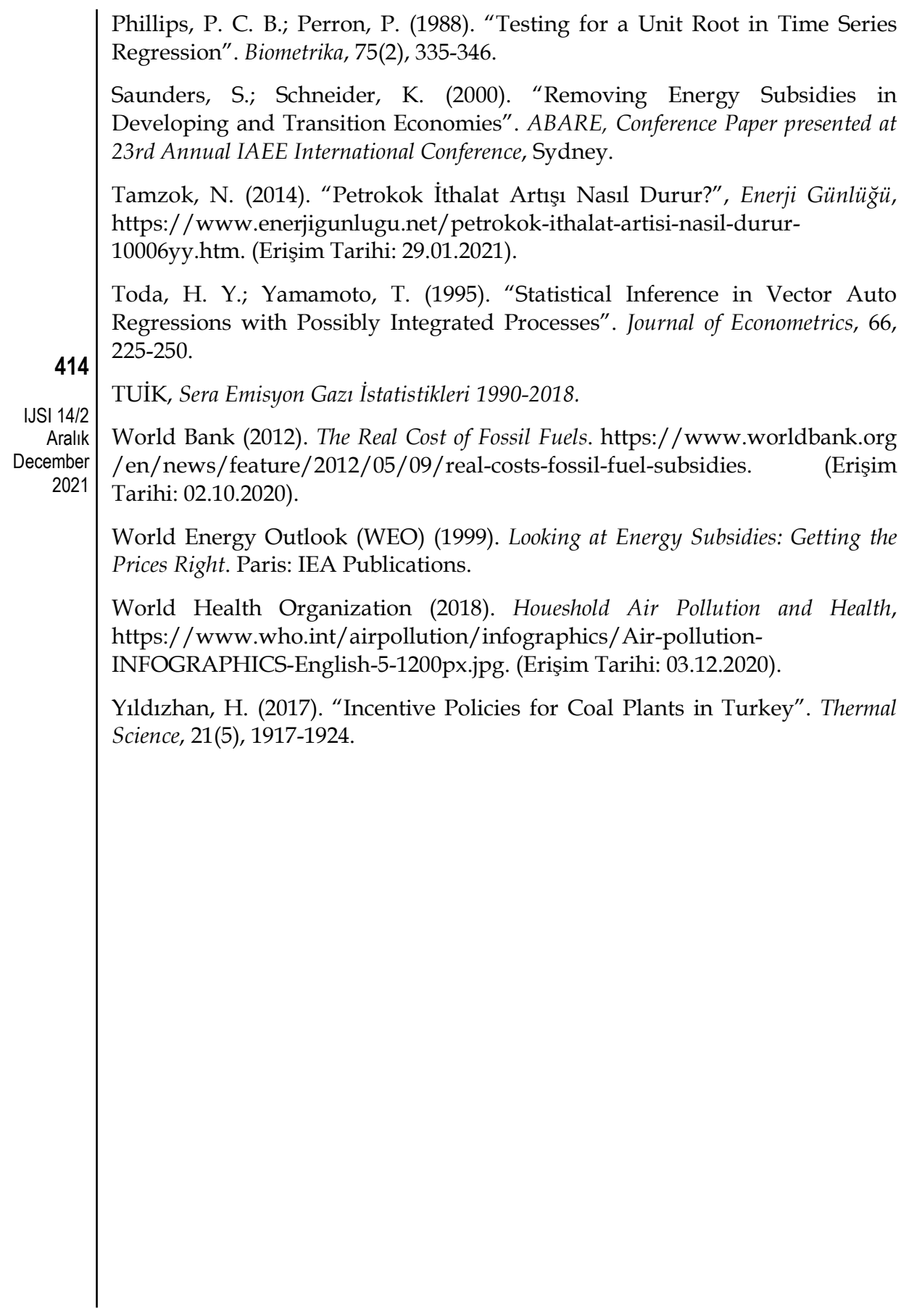




\section{Enerji Sübvansiyonlarının Etkileri ve Türkiye Açısından Ampirik Bir Değerlendirmesi}

\section{SUMMARY}

The energy sector is a sector where public intervention is becoming increasingly common due to its characteristics and importance. The means of public intervention for this sector are subsidies given by the state. Energy subsidies are widely used in all developed and developing countries. Today, many countries allocate $5 \%$ or more of their GDP each year to energy subsidies. Fossil fuels are also the most widely used natural resources in the world to obtain energy. Energy subsidies, which are environmental harms such as the emission of greenhouse gases from fossil fuels, will increase the use of these resources. This means that the economic, environmental and social costs caused by energy sources are gradually increasing. In addition, subsidies that significantly lower energy prices encourage waste production, blur market signals, exacerbate energy price volatility, and increase the density of fuel used in the economy. In addition, subsidies weaken the competitiveness of renewable energy sources and more efficient energy technologies with fossil resources. In line with these facts, efforts are being made to reduce energy subsidies. Studies show that removing the energy subsidy will result in a very significant reduction in greenhouse gas emissions, an environmental indicator, and increased economic efficiency. So removing energy subsidies is an important part of economic growth, fighting poverty and reducing climate change. In this context, countries such as Germany and the United States have taken important steps around the world.For example, in China, various models have been created on the impact of lifting energy subsidies on GDP, CO2 and SO2 emissions, and employment. Anderson and McKibbin (1997) suggested that coal production is significantly subsidized in OECD economies. Coal is also important in developing and transition economies of the gradual removal of subsidies and production subsidies in these countries because of the elimination of the discrepancies in the coal market in global emissions by $8 \%$ reduction will be able to provide. So removing energy subsidies is an important part of economic growth, fighting poverty and reducing climate change. In this context, countries such as Germany and the United States have taken important steps around the world.

Studies on the effects of energy subsidies in Turkey on energy prices, energy consumption, energy imports, current balance, public finance, income distribution are limited. The most important fossil fuel subsidy in our country is related to high emission bitumen and petroleum coke fuels used as inputs in many industrial sectors.

Studies on these issues can lead to subsidy reforms. With this study, the economic, social and environmental consequences of energy subsidies in Turkey will be investigated empirically with Turkey. In this way, as a measure to reduce energy areas that are an economic, social and 


\section{Hakan AKAR, Filiz GİRAY, Mehmet ÇINAR}

environmental problem, the contribution can be made by proposing changes to subsidy policies in these areas. The aim of this study is to examine the environmental, economic and social effects of energy subsidies with the application of Turkey. In order to determine the environmental, economic and social effects of energy subsidies, ARDL co-ordination analysis and TodaYamamoto causality analysis were applied using data from 1990-2018 periods. As part of the Applied Analysis, it decisively determined a long-term oneway relationship between energy subsidies and environmental impacts. Although this relationship remains weak according to both collocation and causality analysis, the results are generally consistent with the literature. In terms of economic impact, according to Toda-Yamamoto, subsidies have no effect on economic growth. Looking only at the results of the synchronization analysis, there is no positive long-term economic relationship of energy subsidies.

Social effects, on the other hand, the Association of energy subsidies with unemployment, according to the analysis of the Synchrony, seems meaningless for a long time. A similar result is seen in other studies. For example, in non-OECD countries, although social policy goals rather than environmental and energy security goals were more supported by the abolition of subsidies, this effect was quite slow.

Based on these findings, it can be said that Turkey also needs to change its energy subsidy policies. Even shifting conventional energy subsidies to renewable energy and energy efficiency could also improve economic efficiency and social well-being. On the one hand, removing or reducing subsidies, on the other hand, additional resources can be provided with income from savings that will be provided in the public budget to reduce environmental damage. The contribution that using these resources in direct social welfare spending, such as education, health and public housing, will create in the fight against poverty will also have a positive impact on GDP in the long term. 